\title{
Approaches to analyzing the rural-urban interface: comprehensive development views from town and countryside
}

\author{
R. Rojas-Caldelas ${ }^{1}$, C. Pena-Salmon ${ }^{1}$, A. Ranfla-González ${ }^{2}$, \\ R. Venegas-Cardoso ${ }^{1}$, O. Leyva-Camacho ${ }^{2}$ \& J. Ley-Garcia ${ }^{2}$ \\ ${ }^{I}$ Faculty of Architecture and Design, \\ Autonomous University of Baja California, Mexico \\ ${ }^{2}$ Institute of Social Sciences, \\ Autonomous University of Baja California, Mexico
}

\begin{abstract}
The urban-rural interface has usually been studied from the point of view of cities with different sectoral interests and very little from rural perspectives. Nevertheless, these kinds of areas need to be studied from both points of view and from comprehensive approaches that could reflect their complexity. Thus the work is oriented to make a comparative analysis of two main approaches to dealing with the rural-urban interface in a Latin-American context: one coming from towns and the other from the countryside, where both of them include the sustainable and a territorial perspective of development. The analysis has taken into account economic, social, environmental and political-institutional issues, as well as urban-rural interactions. Results underline some contributions of such approaches to theory and practice of planning and management of these spaces; such as the value of a complex systems view, planning in different spatial scales and time scenarios, the territory as a support of socio-economic and environmental processes and the role of local actors in this transformation. To conclude, rural development has been arising as an emergent field where medium and small size towns play an important role in linking production with local and global markets and enforcing rural-urban relationships in urban systems.
\end{abstract}

Keywords: rural-urban interface, sustainable development, territorial approach. 


\section{Introduction}

Urban-rural dichotomy was a discourse that lasted from the 1950s until the end of the 1980s. In this period differences between the countryside and the city were clear [1]. However, we now have global economic changes, new forms taken by industrial production, technological innovations in information and communication, decentralization processes and the need to consider environmental issues at different levels of action. All of these factors have contributed to modify the vision and functions of cities and the countryside within a global context [2].

These changes have produced alternative approaches to urban and rural planning, going from sectoral to comprehensive ones. They have the purpose of assessing the role of territory in its various scales and dimensions: geographical, ecological, cultural and political, and so the levels of development, participation of community actors and administrative management of resources. Such topics represent challenges to connect the territorial and environmental discourse with the practice of planning and management of urban and rural areas. Current comprehensive approaches integrate different urban-rural interfaces into the regional analysis.

The work is based on a literature review oriented to comprehensive or holistic approaches that bind the countryside and the city through the territory, without seeking to establish the state of the art in the topic. They not only analyze the treatment given to the issue of interface within the territorial approach from both sides: urban and rural, but also from sustainable development. Therefore this work consists of two parts: the first displays territorial comprehensive approaches to the countryside and the city in a Latin American context. The second deals with constraints facing this kind of approach in the practice of rural-regional and urban-regional planning.

\section{Comprehensive or holistic approaches}

From the point of view of urban development there are three proposals: the strategic spatial planning approach, the city-region and the urban agriculture. All of them share common aspects related to four areas that characterize sustainable development, where all of them are comprehensive and holistic approaches. There are two approaches for rural development: the territorial approach and the new rurality, both of which also share the perspective of sustainability. Each of the approaches talks about urban-rural relationships, the role of human settlements and the regional space as the physical-ecological support for development. These approaches have numerous advantages in analyzing and assessing complex problems and so to making them operative in planning practice, because they are policy oriented.

Under this perspective the territory has been seen as urban-rural-region and represents a key element for the integration of social and economic processes and the physical expansion of settlements over the surrounding ecosystems, giving partial support to numerous activities that they develop. Comprehensive 
approaches emphasize the integral view of complex systems, showing numerous relationships and interdependencies between cities and the countryside [3]. So the territorial approach meets inclusive qualities for the study of phenomena in diverse interfaces: rural-urban, urban-urban and rural-rural.

Whether urban or rural, territorial analysis has also been taken into consideration, institutional arrangements have put the model into practice and it has promoted decentralization processes and community participation in decision making. Another crucial area has been intergovernmental and intersectoral coordination of actions, actors and economic resources to meet common objectives and time targets coming from plans, programs or projects. The territory under this perspective means the physical media on which relies the social, economic and technological development, processes that demand a strategic vision and management to drive through development in the long term to sustain its productivity. This demands a strategic plan that defines core issues and facilitates the concatenation of actions in different periods in time.

Both perspectives necessarily include decentralization of functions of public administration to strengthen local authorities in coordination with other levels of government, the private sector and civil society organizations.

The actors in this framework become leaders in the promotion of endogenous development by building up partnerships and networks, where efficiency becomes a concept equally applicable to the management of natural resources, economic resources and public or private administration.

\subsection{The view from town}

Urban territorial approach: Latin-American urban territorial approach was implemented in the late 1990s and had been expanded as a land use policy -this model [4] was based on the European experience, fig. 1 and table 2. The proposal has integrated all kinds of spatial settlements within a system, from scatter small towns to large metropolis based on planning-action proposals, mainly oriented to overcome social poverty. Also it was seeking the improvement of economic efficiency of the territory to strength political, social and cultural cohesion.

The approach, in despite of starting from a center-periphery vision, rescues the role of regional planning as part of its basic strategy to respond to a more balanced distribution of regions, powers and resources between levels of government planning. The strategy has considered three key issues: a) endogenous development that recognizes the strengths of the territory and opportunities; b) development that conceive objectives of economic efficiency, social cohesion and ecological balance and; c) development based on accountability and governance mechanisms [5].

The proposal also takes into account decentralization of functions from the central government to the local ones by means of an administrative structure to facilitate the management of resources and the organization of communities to plan and act in programs or projects. This implies, to carry out a full stock and intersectoral coordination efforts always bearing in mind the territory as a 
reference, which is usually heterogeneous and diverse to apply standardized formulas.

The proposal affects on urban-rural relations in terms of its functionality with different purposes; one, to support the provision of basic services and transport in small and medium-sized cities in rural areas, particularly those that have problems of decline. Two, promote partnerships between cities and countryside with the aim of strengthening the functionality of the regions. Three, integrate the countryside to cities with territorial strategies for urban areas with the aim of achieving an efficient land use planning and attention to bettering the quality of life of people living in the surrounding city-regions. Four, create territorial networks working over joint projects that promote the association of small and medium-sized cities. Fifth, produce new forms of local governance and relations between State, market and society $[6,7]$.

City - region: this is a variant of holistic or comprehensive approaches. The city-region is a concept that has been worked by Breheny and Rockwood, Ravetz and Rodriguez-Pose [8-10] among others, it emphasizes the aspects of urban metabolism that deal with different type of interactions between the central city with their numerous hinterlands to produce large urban areas or networks of
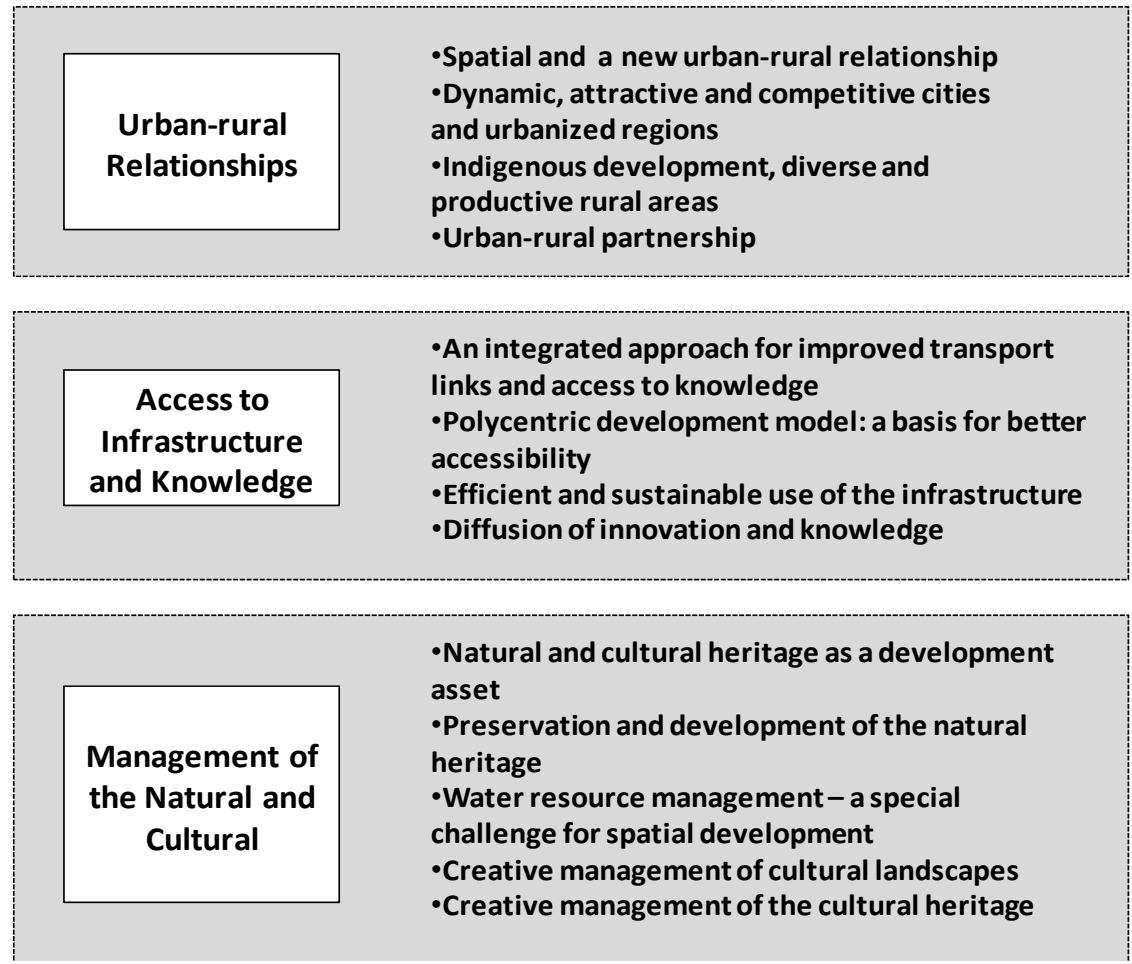

Figure 1: Territorial approach to development in the EU. 
conglomerates, besides integrating sustainability within the model. Although the proposal does not focus in particular on the problems of urban-rural interface, they do emphasize the need to explore the city by layers and their links with the countryside since each of the interfaces reflects on its territory particular conditions that set apart them in problems and possible solutions. Also considers the role the territory "region" has as an ecological support shared by many settlements.

Urban agriculture: parallel to the territorial approach to urban development and to the city-region, there is urban agriculture. This rises as comprehensive approach retrieving and updating urban-rural relationships as a result of proximity of urban centers and a social rural structure lying under a regional space. Thus territory means the bio-physical support of productive activities either for cities or countryside and demand sustainable management of their natural resources. At the same time it embraces the problem of social equity, welfare and health that brings with it the malnutrition associated with urban and rural poverty. Also claims for employment generation to have complementary incomes to improve domestic economy or just for subsistence of people. From the point of view of environment; this proposal is driven to the conservation of ecosystems through the provision of environmental services, urban greening, improvement of microclimatic conditions, and reduction of ecological footprint, promotion of biodiversity, environmental education and recreation. But at the same time is looking for the management of wastes, environmental restoration of lands and ecosystems and efficiency in production [11-15].

\subsection{The view from countryside}

Sustainable rural development of the territory: this approach has its roots in the proposal of the LEADER program developed in Europe and adjusted to suit the Latin American conditions in the late 1990s and early 2000, tables 1 and 2. This policy has set the legal basis in some Latin American countries to implement sustainable rural development. The territorial approach is focused on social and environmental interactions, to promote the integration of productive systems on the countryside and to produce welfare and the inclusion of vulnerable people and marginalized social groups. The territory functions as integrator of agents, markets and public policy in order to generate economic development [16-19].

Territorial rural development represents a comprehensive, multidimensional, timeless and multisectoral perspective that articulates the rural-regional space. This transformation of the countryside leads to create internal conditions of diversification of the rural economy to turn towards the establishment of new networks, linkages with new markets and access to information and knowledge. Within a global economy framework is convenient the integration of efforts between countryside and city to surmount problems on different scales, resulting in new forms of partnership that share the cooperation and coordination among public, private and social sectors.

New rurality: it is a theoretical perspective moving along to the territorial approach, where territorial issues are not a central part of its discourse. Although 
the proposal focuses on the pluri-activity and multi-functionality of the countryside, it stresses the importance to change policies from sectoral to territorial, due to their poor results in rural development in Latin American countries. New rurality seeks four major challenges: a) moving from agriculture to rural non-farm activities; b) augmenting flexibility and feminization of rural labor; c) increasing the importance of international emigration and backward immigration and; d) beginning the reduction of differences between the rural and urban way of living and the increasing interactions among them [20].

This movement also involves the occupation of the traditional rural areas by modern activities which consider the incorporation of industry and human settlements, in addition to several kinds of agriculture, types of companies, new ways to build up networks, vulnerability of food production, relocation production factors linked to competitively and to particular local forms of organization, knowledge and technological development.

Table 1: $\quad$ Territorial rural development in Latin America.

\begin{tabular}{|c|c|c|c|c|}
\hline Dimensions & Environmental & Social & Economic & $\begin{array}{l}\text { Politicaland } \\
\text { Institutional }\end{array}$ \\
\hline Environmental & $\begin{array}{l}\cdot \text { Localnatural protected } \\
\text { areas }\end{array}$ & & & \\
\hline Social & $\begin{array}{l}\text {-Environmental } \\
\text { education } \\
\text {-Management of wastes } \\
\text { - Basic sanitary services }\end{array}$ & \begin{tabular}{|l|}
$\cdot$ Culture and \\
sustainability \\
$\cdot$ Human development \\
$\cdot$ Self local \\
management and \\
partnerships \\
$\cdot$ Education and \\
training \\
$\cdot$ Health and others \\
public services
\end{tabular} & & \\
\hline Economic & $\begin{array}{l}\cdot \text { - Clean production } \\
\cdot \text { Environmental } \\
\text { management systems } \\
\cdot \text { Agricultural in fragile } \\
\text { areas } \\
\cdot \text { Environmentaservices } \\
\cdot \text { Ruralamenities }\end{array}$ & \begin{tabular}{|l|}
$\cdot$ Land reform \\
$\cdot$ Nonagricultural \\
employmentand \\
incomes \\
$\cdot$ Domesticagriculture \\
$\cdot$ Foodsecurity
\end{tabular} & \begin{tabular}{|l|}
-Accessibility to \\
productive \\
infrastructure \\
$\cdot$ Clusters and \\
productive networks \\
$\cdot$ Commercialization \\
$\cdot$ Produce \\
certifications
\end{tabular} & \\
\hline $\begin{array}{l}\text { Politicaband } \\
\text { Institutional }\end{array}$ & $\begin{array}{l}\text {-Watershed managemen } \\
\text { institutions } \\
\text {-Waterusers } \\
\text { associations }\end{array}$ & \begin{tabular}{|l|}
$t \cdot$ Development of \\
social and human \\
capital \\
$\cdot$ Socialorganizations \\
$\cdot$ Citizendevelopment
\end{tabular} & \begin{tabular}{|l|} 
Producers \\
organizations \\
$\cdot$ Technical assistance \\
$\cdot$ Technological \\
innovation
\end{tabular} & $\begin{array}{l}\text {-Local governance } \\
\text {-Localpartnerships } \\
\text {-Partnerships actions } \\
\text { among territories }\end{array}$ \\
\hline
\end{tabular}

Source: Sepulveda et al. [18]. 
Table 2: Comparative comprehensive proposals to urban and rural development.

\begin{tabular}{|c|c|c|c|}
\hline & $\begin{array}{c}\text { Territorial rural } \\
\text { development and new } \\
\text { rurality }\end{array}$ & $\begin{array}{c}\text { Urban spatial planning, city- } \\
\text { region and urban } \\
\text { agriculture }\end{array}$ & $\begin{array}{c}\text { Sustainable } \\
\text { Development }\end{array}$ \\
\hline & $\begin{array}{c}\text { - Sustainable management of } \\
\text { natural resources } \\
\text { - Conservation of ecosystems } \\
\text { and environmental services. } \\
\text { - Spatial planning of rural-urban } \\
\text { relationships } \\
\text { - Expansion controls of urban } \\
\text { centers over rural areas. } \\
\text { - Sustainable management of } \\
\text { productive activities. }\end{array}$ & 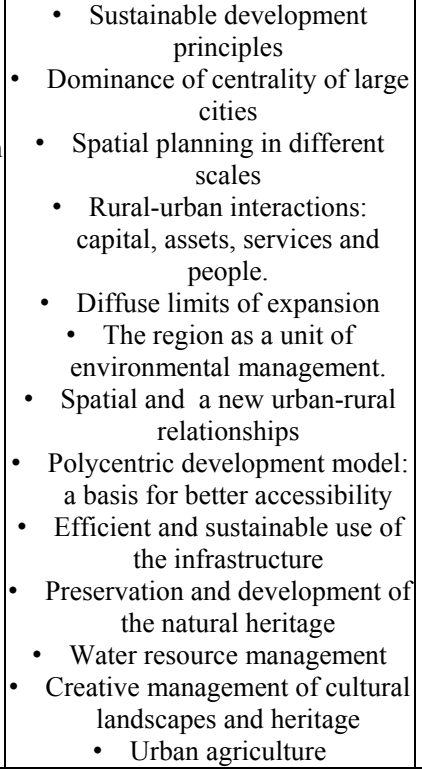 & $\begin{array}{c}\text { - Sustainable } \\
\text { management of } \\
\text { renewable natural } \\
\text { resources and } \\
\text { consumption reduction } \\
\text { non renewable } \\
\text { resources. } \\
\text { - Conservation of } \\
\text { ecosystems and } \\
\text { environmental services. } \\
\text { - Spatial planning and } \\
\text { management. } \\
\text { Efficient management } \\
\text { of input-output } \\
\text { exchanges within the } \\
\text { urban-region system. } \\
\text { Risk management. }\end{array}$ \\
\hline & $\begin{array}{c}\text { - } \begin{array}{c}\text { Integration to the global } \\
\text { economy }\end{array} \\
\text { Economy based on agriculture } \\
\text { but widened to non } \\
\text { agricultural activities. } \\
\text { Equity and regional } \\
\text { development } \\
\text { - Endogenous development } \\
\text { - New technologies and their } \\
\text { role in the transformation of } \\
\text { production and current } \\
\text { patterns of urban growth. } \\
\text { Medium and small size cities } \\
\text { are key elements for } \\
\text { development of: industry, } \\
\text { services, research and } \\
\text { technology, tourism and } \\
\text { recreation. } \\
\text { Production of organic } \\
\text { agriculture and new produce. } \\
\text { Rural industrialization: agro- } \\
\text { industrial clusters } \\
\text { Economic competitively }\end{array}$ & $\begin{array}{c}\text { - New technologies and their role } \\
\text { in the transformation of } \\
\text { production and current patterns } \\
\text { of urban growth. } \\
\text { Economic competitively and the } \\
\text { restructuring of the territory due } \\
\text { to globalization. } \\
\text { - Dynamic, attractive and } \\
\text { competitive cities and urbanized } \\
\text { regions. } \\
\text { Indigenous development, diverse } \\
\text { and productive rural areas. } \\
\text { An integrated approach for } \\
\text { improved transport links and } \\
\text { access to knowledge. } \\
\text { Diffusion of innovation and } \\
\text { knowledge. } \\
\text { Natural and cultural heritage as } \\
\text { development assets. }\end{array}$ & $\begin{array}{l}\text { Economic growth, } \\
\text { competitively and } \\
\text { efficiency } \\
\text { Restructure of } \\
\text { production processes } \\
\text { and the territory. } \\
\text { - Production processes } \\
\text { linked to different } \\
\text { spatial scales. } \\
\text { Labor markets linked to } \\
\text { better conditions of } \\
\text { quality of live and } \\
\text { productive } \\
\text { infrastructure. } \\
\text { Cities means centers } \\
\text { for knowledge } \\
\text { innovation and } \\
\text { technological } \\
\text { development to } \\
\text { facilitate work in } \\
\text { networks. }\end{array}$ \\
\hline
\end{tabular}


Table 2: $\quad$ Continued.

\begin{tabular}{|c|c|c|c|}
\hline & $\begin{array}{c}\text { Spatial rural } \\
\text { development and new } \\
\text { rurality }\end{array}$ & $\begin{array}{c}\text { Urban spatial planning } \\
\text { and city-region }\end{array}$ & Sustainable Development \\
\hline 兽. & $\begin{array}{c}\text { - Poverty reduction. } \\
\text { Agriculture production as } \\
\text { a food safety strategy for } \\
\text { vulnerable groups. } \\
\text { - Territorial social and } \\
\text { cultural networking. } \\
\text { - Public participation and } \\
\text { decision making process. } \\
\text { - Eomen empowerment } \\
\text { - Youth employment } \\
\text { generation } \\
\text { Social and human capital }\end{array}$ & $\begin{array}{l}\text { The role of local } \\
\text { actors and } \\
\text { stakeholders in the } \\
\text { promotion and } \\
\text { implementation of } \\
\text { development }\end{array}$ & $\begin{array}{c}\text { - Equity, social justice and } \\
\text { well being } \\
\text { - Catering basic population } \\
\text { needs: housing public } \\
\text { utilities and public services. } \\
\text { - Public participation } \\
\text { - Social and human capital } \\
\text { - Diverse cultural and heritage } \\
\text { values of the territory. }\end{array}$ \\
\hline 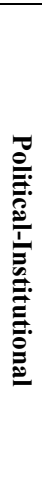 & $\begin{array}{c}\text { - Institutional changes and } \\
\text { modification of the legal } \\
\text { framework. } \\
\text { - Collaborative work and } \\
\text { local governance. } \\
\text { - Creation of local } \\
\text { partnerships among public, } \\
\text { private and civil society. } \\
\text { - Social and productive } \\
\text { planning and management } \\
\text { of the territory. } \\
\text { Multisectoral, } \\
\text { multifunctional and } \\
\text { intergovernmental } \\
\text { planning. }\end{array}$ & $\begin{array}{c}\text { - Coordination and } \\
\text { management of } \\
\text { intersectoral and } \\
\text { government issues } \\
\text { - Government } \\
\text { decentralization } \\
\text { - Down-up planning } \\
\text { process } \\
\text { - Urban-rural } \\
\text { partnership }\end{array}$ & $\begin{array}{l}\text { - Institutional changes and } \\
\text { modification of the legal } \\
\text { framework. } \\
\text { - Regulation enforcement } \\
\text { - Governance by local actors } \\
\text { - Social and productive } \\
\text { networks } \\
\text { - Efficient and transparency } \\
\text { management of resources }\end{array}$ \\
\hline
\end{tabular}

\section{Reflections of comprehensive approaches}

Although these approaches are recent in Latin American, yet its results have not been significant to reverse the trends of sectoral approaches in terms of planning and management of urban and rural development. Current limitations that have been reported were due to a partial implementation of the legal framework at central level, but not at State and Municipal ones, where there is still a lot of work to do in order to feedback the model.

Particularly in Mexico, there is a law to support Sustainable Rural Development under the territorial approach, but urban development is not walking at the same time. Although, federal government have tried to implemented it by means of a methodological proposal (it integrates the territorial approach and sustainable management of natural resources), that is not compulsory by law, which means an obstacle to be operative. Other approaches to urban-rural development have been closer to support theoretical aspects and methodological tools for the analysis, assessment and design of strategies or 
policies. The coming paragraphs will deal with their main limitations related to the theory and the practice of planning.

Theoretical: These approaches offer multiples perspectives on the same research object -urban and rural development- contributing by different disciplines that enrich the setting of problems and likely solutions. At the same time they emphasize the relationship between social and economic processes and their territorial distribution and the possible impacts that could have throughout the time and in different scales, besides they could set conditions to develop collaborative, multi-disciplinary and trans-disciplinary work.

These approaches demand long term strategic planning, which is difficult to implement in developing countries, given the vulnerability of their economies and the short-term social pressures they need to adjust in a continuous way.

Complex systems view requires changes to the institutional management structure that enable to respond integrated and coordinated in different levels of government and with other sectoral agencies. Changes that are only possible when are linked to the amendments to the legal framework. Such modifications are regularly slow to implement from top-down levels since they require training of officers, planners, practitioners and service providers, to update the infrastructure and local regulations, as well as cultural changes in society.

Even when the proposal of endogenous development has major advantages to raise levels of welfare and economic growth, it has his own limitations since in some rural development experiences do not allow local actors to have a regional perspective of problems and to promote synergies with other settlements supported on public, private, social and academic partnerships. Other higher levels of interaction are seen as potential social and economic conflicts with external actors.

Planning the rural-urban interfaces as differentiated spaces is still a challenge, but it could be integrated under regional planning, meanwhile legal and institutional changes to urban and rural planning take place.

Governmental experience of participatory and collaborative work among government, private, civil society and academia has been positive at the beginning and during the making of strategic plans exercises, but not in regard to management and monitoring of actions of projects. The lack of economic resources has undermined governmental supervision and technical assistance to communities to consolidate economic and social projects. The same has happened with the academia, once the project has finished there is no monitoring of actions to feedback planning and management processes.

From the technical point of view of planning, territorial development proposals require by regulations to integrate data into a geographic information system. Infrastructure capabilities and qualified human resources are located on planning departments of large and medium-sized cities or in institutions of higher education and research centers, capabilities that do not exist in small towns and rural areas. It makes difficult updating, monitoring and assessment of actions. In a similar case is local management, lacking of professional human resources and from an administrative structure to support development project. 
Territorial planning which is currently done, do not necessarily reflects territorial bioregional behavior of productive or environmental activities whether they are urban or rural. In most cases are responding to operational ways of public management of economic resources throughout municipalities. Although there is the possibility of municipal associations to attack regional problems, few examples can be found. Those that have been developed respond overall, to productive projects and not to strengthen the infrastructure and public services of the urban system in rural areas.

Urban planning and urbanism schools still have an urban bias towards planning metropolitan areas, large and medium-sized cities, but they are absents in the matter of rural settlements, therefore rural planning is done by the ministry of agriculture with a poor enhancement of urban- rural interactions.

Nowadays in Mexico planning remains sectoral, Sustainable Rural Development is still in the ministry of agriculture, Urban Development in the ministry of Social Development and environmental protection in the ministry of The Environment and Natural Resources. Although in theory there is coordination among them, in practice there are obstacles to achieve join projects.

The issue of urban-rural interactions or interfaces is still an urban issue linked to the planning of metropolis, large and medium-sized cities, but not linked with other interactions to strengthen the system of cities at lower hierarchies, especially in the rural areas outside of the scope of big cities.

Administration: while in Mexico there have been some changes in legislations, not all of them have been done at the same time and coupling similar approaches (territorial approach and sustainable development), such is the case of the Sustainable Rural Development against the Human Settlements (Urban Development). That represents an obstacle to apply the same criteria to the planning and management of urban and rural development. Despite of the changes, economic resources are managed in a sectoral way, moved by different visions, objectives, goals, priorities and political interests, making difficult coordination and convergence of actions in most cases.

Although laws talk about coordination and convergence of actions to boost rural or urban development, reality shows few cases where this formula works, since resources are still sectoral and not necessarily coordinated vertically to the various governmental authorities, or horizontally by agreements between sectoral agencies. Results show little improvements in welfare levels and economic productivity of specific communities and regions. Most of the cases are perceived as a sprawl of economic resources among several projects driven by families, communities or entrepreneurs associations. Major federal funds are aimed to overcome urban and rural poverty problems and then resources are not necessarily contributing to economic and social development.

One of the purposes of territorial approaches is to support local empowerment, despite it has been carried out the transference of functions to the local level through municipal committees, in practice there is a lack of representativeness of certain community actors, due in part to the domain still exerted by some political or economic community leaders, the limited capacity of organization of people, the lack of technical advice for the management of 
resources, and the fact that communities have been used to a certain way of paternalism from the State that has diminished local power to undertake their own projects. All these changes are slow and difficult to implement in the short term, because they imply cultural patterns to be modified.

\section{Conclusions}

Current implementation of the territorial approach in Latin America and in Mexico has not yet tested its effectiveness with regard to past sectoral approaches. It is relevant to overcome many inertias propitiated by sectoral approaches, urban and rural poverty, besides the need to complete the processes of implementation of legislation and regulation to lower levels of administration.

Despite of the fact that the territorial approach is a common approach for urban and rural development, reality demonstrates still a gap between urban and rural planning and their respective interactions.

\section{References}

[1] Adell, G., Theories and models of the peri-urban interface: changing conceptual landscape, Draft for discussion, Development Planning Unit, pp. 38. 1999.

[2] Rojas-Caldelas, R., Planeación del desarrollo rural: elementos del marco regional y local para el caso de Bahía de los Ángeles (Chapter 2). Construyendo el futuro, visiones para un desarrollo rural sustentable en las comunidades de la Baja California, ed. A. L. Quintanilla-Montoya, UABCPorrúa, Mexico, pp. 37-91, 2007.

[3] Antequera, J. El potencial de la sostenibilidad de los asentamientos humanos, Caixa de Sabadel. 2004. Online. http://www.eumed.net/ libros/2005/ja-sost/

[4] ESDP. Towards balanced and sustainable development of the territory of the European Union, Published by the European Commission. 1999. Online. http://ec.europa.eu/regional_policy/sources/docoffic/official/ reports/pdf/sum_en.pdf

[5] Delgadillo-Macias, Planeación regional y ordenamiento territorial en Mexico. Senado de la Republica, Camara de Diputados, CONAGO, PNUD, IIEc/UNAM, UAM. 2007. Online. http://www.senado.gob.mx/comisiones/ LX/desarrolloregional/content/foros/desarrollo_regional/Javier_Delgadillo_ Macias.pdf

[6] Dühr, S. Stead, D. Zonneveld, The Europeanization of Spatial Planning through Territorial Cooperation, Planning, Practice \& Research, Vol. 22, No. 3, pp. 291 - 307, 2007.

[7] Sartorio, F.S., Strategic Spatial Planning: A historical review of approaches, its recent revival, and an overview of the state of the art, disP 162-3, pp. 26-40, 2005. 
[8] Breheny, M, \& Rockwood, R., Planning for sustainable city-region, in Blowers, Planning for a sustainable environment, Earthscan: London, pp. 150-280, 1993.

[9] Ravetz, J., City-Region 2020: integrated planning for a sustainable environment. Earthscan: London, pp. 49-62, 2001.

[10] Rodriguez-Pose, A., The Rise of the "City-region" Concept and its Development Policy Implications, European Planning Studies, Vol. 16, No. 8, pp.1025-1046, 2008.

[11] Mougeot, L. J. A., AGROPOLIS: The Social, Political and Environmental Dimensions of Urban Agriculture, Earthscan, London, 2005.

[12] Puello-Bedoya, M., Agropolis o el fin de la ciudad-territorio aportes conceptuales para un planteamiento físico de base agropolitana, Bitácora Urbano Territorial, Vol. 1, No. 9, pp. 43-53, 2005.

[13] Van Veenhuizen, R., Cities farming for the future: urban agriculture for green productive cities, IDRC Books, pp. 2-17 and 53-72, 2006.

[14] Ruiz-Rivera, N. \& Delgado-Campos, J. Territorio y nuevas ruralidades: un recorrido teórico sobre las transformaciones de la relación campo-ciudad, Eure, Vol. XXXIV, No. 102, pp. 77-95, 2008. Online http://redalyc.uaemex.mx/src/inicio/ArtPdfRed.jsp?iCve=19610205\&iCve Num $=10450$

[15] Redwood, M., Agriculture in Urban Planning: Generating Livelihoods and Food Security, Earthscan, London, 2009.

[16] Schejtman, A. \& Berdegue, J. A., Desarrollo territorial rural, RIMISP, Santiago de Chile, 2004. Online http://www.rimisp.org/getdoc.php? docid $=870$

[17] Schejtman, A., Desarrollo Rural: condicionantes, experiencias y búsqueda de nuevos paradigmas, FODEPAL, 2004. Online http://www.fodepal.es/ bibvirtual/PAP/papelesnew\%20pdf/schejtmannew.pdf

[18] Sepulveda, S., Rodriguez, A., Echeverri, R. \& Portilla, M. El enfoque territorial del desarrollo rural, Instituto Interamericano de Cooperación para la Agricultura, San José de Costa Rica, 2003. Online http://www.infoagro.net/shared/docs/a6/Libro_ETDR.pdf

[19] Delgadillo-Macias, J., Dimensiones territoriales del desarrollo rural en America Latina, problemas del desarrollo económico, Revista Latinoamericana de Economía, Vol. 37, núm. 144, pp. 97-120, 2006.

[20] Kay, C., Reflections on Latin American Rural Studies in the Neoliberal Globalization Period: A New Rurality? Development and Change, 39(6): pp. 915-943, 2008.

[21] Meeus, S.T. \& Gulinck, H., Semi-Urban Areas in Landscape Research: A Review, Living Reviews, Landscape Research, Leibniz Centre for Agricultural Landscape Research, 2, 3, pp. 1-45, 2008. 